\title{
BISNIS KULINER CIMOL
}

Makalah Ini Disusun untuk Memenuhi Tugas Final pada Mata Kuliah Kewirausahaan

Dosen Pengampuh : Ibu Dra. Hj. Nuraeni Gani, MM

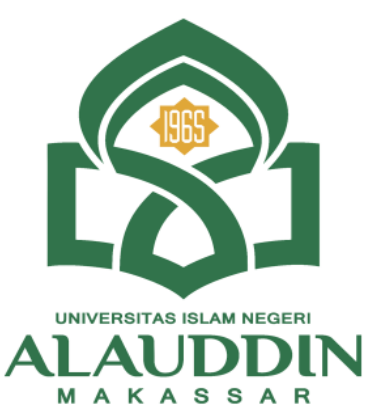

Kelompok 2 :

$\begin{array}{ll}\text { Mirnawati } & (90500120100) \\ \text { Evi Sugiatni } & (90500120103) \\ \text { A. Syahrul Ramadhan } . R & (90500120112) \\ \text { Riana Putri Sandita } & (90500120120) \\ \text { Rahmi } & (90500120121)\end{array}$

PERBANKAN SYARIAH

FAKULTAS EKONOMI DAN BISNIS

UNIVERSITAS ISLAM NEGERI MAKASSAR

TAHUN 2021 


\section{KATA PENGANTAR}

Puji syukur kehadirat Allah SWT yang telah memberikan rahmat dan hidayah-Nya sehingga Saya dapat menyelesaikan tugas makalah yang berjudul "BISNIS KULINER CIMOL" ini tepat pada waktunya. Adapun tujuan dari penulisan dari makalah ini adalah untuk memenuhi tugas dosen pada mata kuliah Kewirausahaan . Selain itu, makalah ini juga bertujuan untuk menambah wawasan tentang Kewirausahaan di tinjau dari BISNIS KULINER CIMOL bagi para pembaca dan terutama bagi penulisnya.

Kami mengucapkan terima kasih kepada Ibu Dra. Hj. Nuraeni Gani, MM selaku Dosen Pengampu Mata Kuliah Kewirausahaan yang telah memberikan tugas ini sehingga dapat menambah pengetahuan dan wawasan Kami sesuai dengan bidang studi yang kami tekuni. Kami juga berterima kasih kepada Pihak-pihak yang telah membantu kami dalam meyusun makalah ini dan juga telah membagi sebagian pengetahunnya sehingga kami dapat menyelesaikan makalah ini.

Kami menyadari, makalah yang kami tulis masih jauh dari kata sempurna. Oleh karena itu, kritik dan saran yang membangun sangat kami nantikan demi kesempurnaan makalah ini.

Gowa, 15 Desember 2021

Kelompok 2 


\section{DAFTAR ISI}

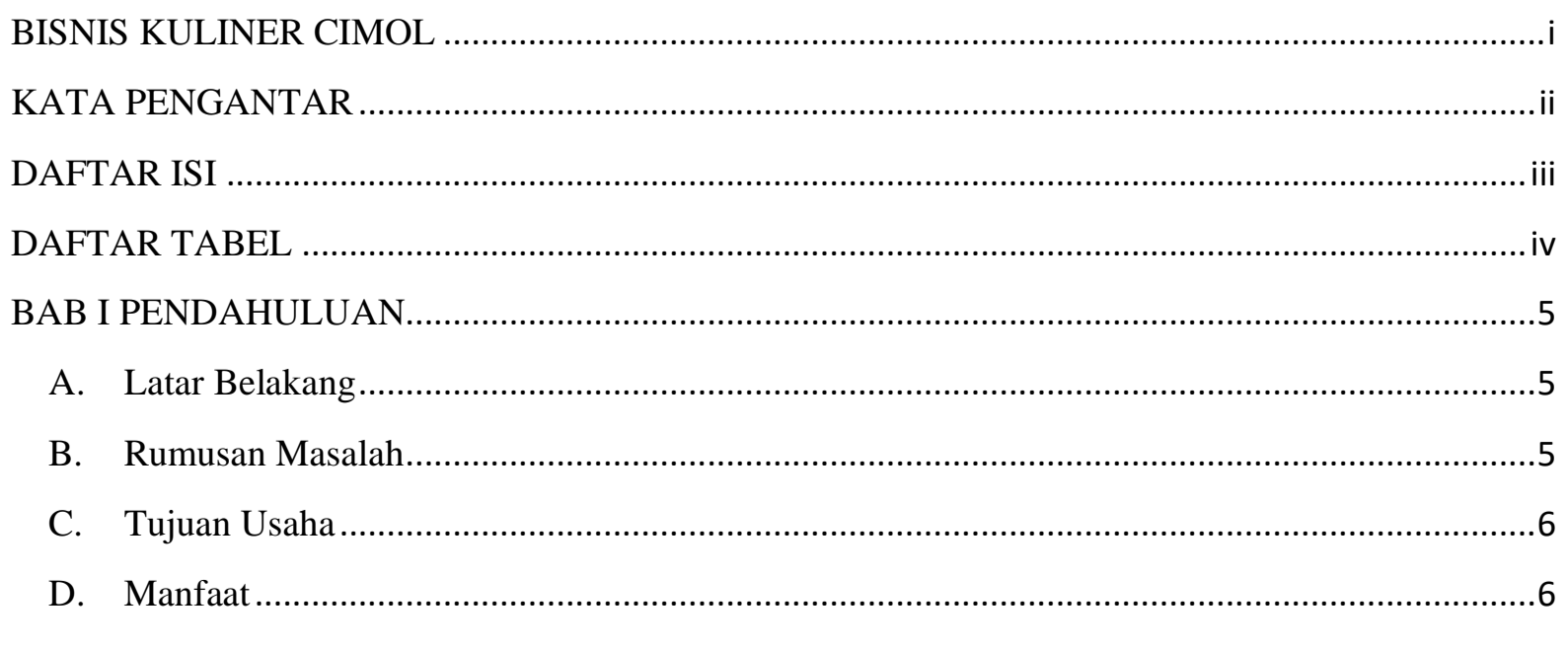

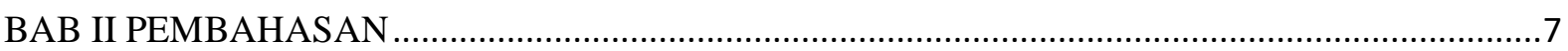

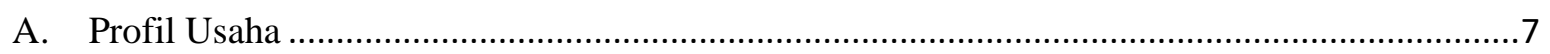

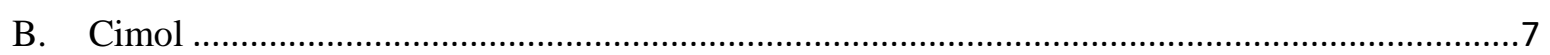

C. Persiapan Dan Proses Pembuatan Cimol ...........................................................................

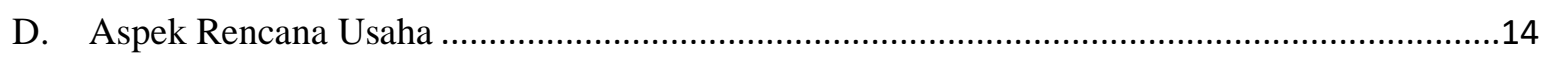

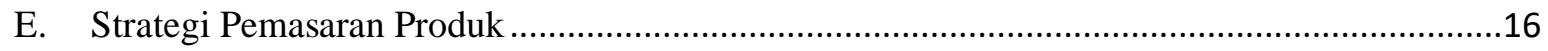

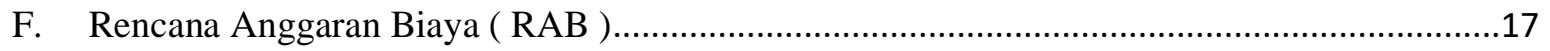

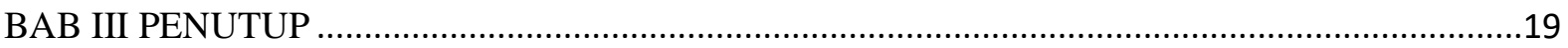

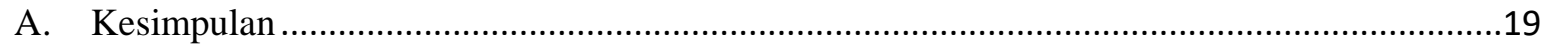

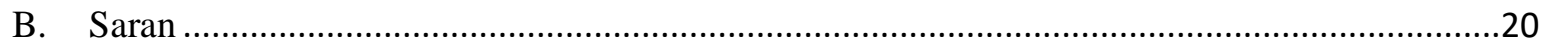

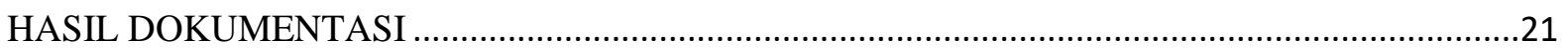

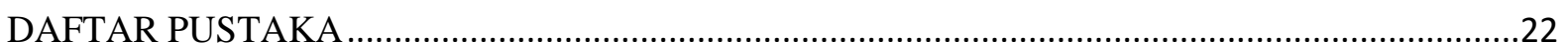




\section{DAFTAR TABEL}

Tabel 1 Profil Usaha

Tabel 2 Pemilik/Pengurus usaha

Tabel 3 Bahan dan Peralatan

.10

Tabel 4 RAB Peralatan ( Fix Cost )

Tabel 5 RAB Bahan ( Variable Cost ) .17 


\section{BAB I \\ PENDAHULUAN}

\section{A. Latar Belakang}

Pada zaman seperti sekarang ini banyak sekali makanan ringan yang sedang dijual di pasaran yang biasa masyarakat sebut dengan cemilan. Jenis cemilan yang banyak kita jumpai di warung, atau pasar yang ada disekitar kita adalah cemilan cimol. Dari sekian banyaknya jenis cemilan baik itu cemilan basah atupun cemilan kering yang ada saat ini banyak sekali jenis makanan modern yang terbuat atau buatan pabrik canggih yang fterjual di warung atau pasaran yang ada di dekat kita. Sedangkan industry rumahan yang di pakai untuk membuat makanan ringan seperti cimol bisa kita dapatkan dengan mudah di pasaran. Sama halnya yang kita ketahui bahwa para konsumen di Indonesia banyak sekali masyarakat bahkan hampir semuanya menyukai makanan ringan atau cemilan.

Makanan ringan merupakan sebuah makanan yang biasanya di konsumsi oleh masyarakat pada saat mereka sedang istirahat atau bersantai. Ataupun mereka sedang di pertengahan sarapan dan makan siang mereka. Kondisi perkulihan yang saat ini mungkin jadwal perkulihan para mahasiswa sangat padat sehingga terkadang mahasiswa lupa makan siang atau sarapan bahkan makan malam sehingga cemilan atau makanan ringan lah yang menjadi pengganti makanan pokok mereka. Selain dari itu terkadang juga harga makanan yang cukup terbilang mahal di kalangan mahasiswa sehingga mereka lebih memilih

\section{B. Rumusan Masalah}

1. Mengidentifikasi bisnis tentang cimol?

2. Bagaimana persiapan dan proses pembuatan cimol ?

3. Bagaimana aspek rencana usaha?

4. Bagaimana strategi pemasaran pada bisnis risoles ?

5. Mengidentifikasi rencana anggaran biaya ( $\mathrm{RAB}$ ) pada bisnis cimol ? 


\section{Tujuan Usaha}

Adapun tujuan dari usaha yang kami buat adalah sebagai berikut :

1. Memperoleh keuntungan.

2. Melestarikan dan mengenalkan produk khas daerah kepada seluruh masyarakat.

3. Memberikan rasa yang berbeda dengan produk yang lain.

\section{Manfaat}

1. Baik bagi kesehatan saluran pencernaan.

2. Baik bagi keseluruhan tulang

3. Menjaga berat badan agar tetap ideal

4. Menjaga tekanan darah 
BAB II

PEMBAHASAN

\section{A. Profil Usaha}

Tabel 1 Profil Usaha

\begin{tabular}{|c|l|l|}
\hline 1. & Nama usaha & Cimol Kenyoy \\
\hline 2. & Bidang Usaha & Industri Rumahan \\
\hline 3. & Jenis Produk/Jasa & Makanan ringan \\
\hline 4. & Mulai Berdiri & 15 November 2021 \\
& & \\
\hline
\end{tabular}

Tabel 2 Pemilik/Pengurus usaha

\begin{tabular}{|l|l|l|}
\hline No. & \multicolumn{1}{|c|}{ Nama } & \multicolumn{1}{|c|}{ Jabatan } \\
\hline 1. & A. Syahrul Ramadhan Rasyid & Pemimpin \\
\hline 2. & Mirnawati & Bendahara \\
\hline 3. & Rahmi & Anggota \\
\hline 4. & Evi Sugiatni & Anggota \\
\hline 5. & Riana Putri Sandita & Anggota \\
\hline
\end{tabular}

\section{B. Cimol}

Cimol berasal dari aksara asli sunda, cimol ini terbuat dari bahan dasar tepung kanji. Cimol berasal dari kata aci digemol yang artinya tepung aci yang dibuat dan dibentuk seperti kelereng atau bulat-bulat kecil.

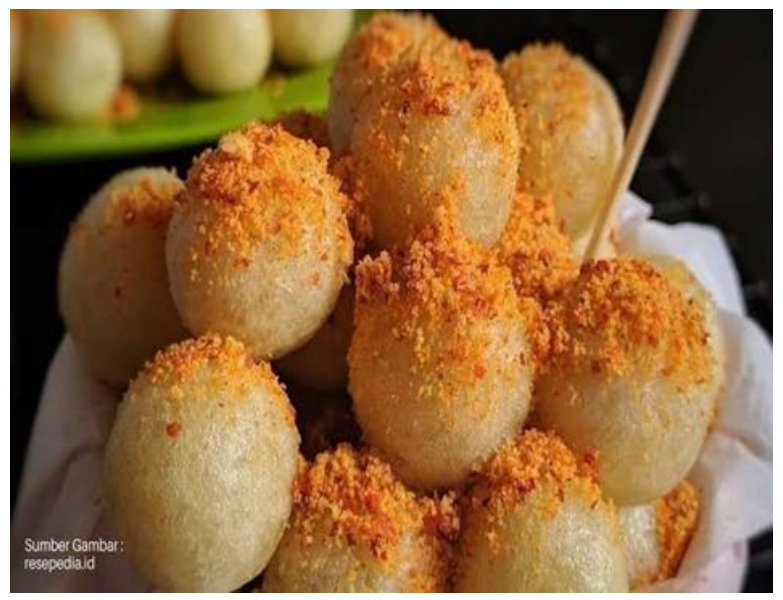


Cimol ini adalah salah satu jajanan yang berbahan dasar dari tepung kanji. Jajanan atau cemilan ini yang terbuat dari bahan dasar kanji atau tepung aci yang sebenarnya memang sangat digemari oleh masyarakat baik itu anak kecil maupun orang dewasa. Bahan yang cukup sederhana ini yang membuat cemilan ini jarang di minati oleh masyarakat karena terlalu simple. Justru makanan seperti cilok, cimol dan cireng yang menjadi kegemaran dari seluruh masyarakat yang ada di sekitar kita. Proses pembuatan cilok dan cimol hampir sama akan tetapi yang membedakan keduanya adalah kalo cilok dikukud di atas air yang sedang mendidih sedangkan cimol itu digoreng kemudian diberi bumbu-bumbu untuk menambah cita rasa kesedapannya.

Cimol ini sering kita jumpai di pinggir jalan karena begitu banyaknya masyarakat yang mampu membuat jenis cemilan yang satu ini. Bahkan jenis jajanan ini sering sekali di jual di lingkugan sekolahan di bebrapa wilayah nusantara. Yang pastinya harganya yang tergolong murah di kantong para siswa dan siswi, jajanan ini juga digemari oleh beberapa kalangan seperti anak kecil mahasiswa, orang tua dll. Produk cimol ini sama dengan cimol yang biasanya di jual di sekiar kita akan tetapi ada bebrapa macam cimol yaitu diantaranya: cimol yang digoreng dengan telur, cimol digoreng biasa dan cimol yang senagaja dibuat dalam keadaan basah ataupun kering lalu kemudian digoreng yang biasa disebut dengan cimol basah.

Adapun manfaat dari jajanan satu ini diantaranya :

\section{Baik bagi kesehatan saluran pencernaan}

Ahli kesehatan telah menyebutkan bahwa tepung kanji ternyata kaya akan kandungan tembaga, selenium, mangan,kalsium, besi, asam folat, asam pantotenat, serat, hingga vitamin B6. khasiat dari serat yang terkandung dalam tepung kanji inilah yang bisa mencegah konstipasi, kanker usus besar, dan melancarkan pencernaan.

\section{Baik bagi kesehatan tulang}


Kandungan kalsium, zat besi, dan vitamin $\mathrm{K}$ yang ada dalam tepung kanji membuat jajanan yang terbuat dari bahan tepung kanji ini sangatlah bermanfaat untuk bantu menjaga bagi kesehatan tulang. Selain mencegah masalah kesehatan tulang seperti osteoarthritis atau osteoporosis, mengkonsumsi jajanan cimol juga akan membantu kandungan protein dalam harian kita.

3. Menjaga berat badan tetap ideal

Ternyata tepung kanji tidak memiliki kandungan kolesterol atau lemak yang jenuh, sehingga cukup aman untuk dikonsumsi asalkan dalam jumlah yang tidak berlebihan. Mengkonsumsi cimol yang terbuat dari tepung ini tentu akan membuat berat badan kita tetap ideal.

4. Menjaga tekanan darah

Kandungan kalium yang terdapat di dalam tepung kanji ini ternyata bisa menurunkan stress pada pembuluh darah dan juga arteri. Tidak hanya itu, kalium ternyata mampu menjaga keseimbangan cairan di dalam tubuh kita.

5. Mencegah anemia

Kandungan zat besi yang ada di dalam tepung kanji ternyata bisa membantu kita dalam mencegah dari penyakit anemia sekaligus menjaga dalam kelancaran sirkulasi darah.

\section{Membantu Memelihara Kesehatan Pencernaan}

Tidak ada yang dapat kita sangkal bahwa salah satu manfaat kesehatan tepung kanji adalah untuk membantu pencernaan. Karena serat makanan yang dapat dengan mudah ditemukan ditepung kanji.

\section{Persiapan Dan Proses Pembuatan Cimol}

Menjual jajanan cimol adalah salah satu bisnis atau usaha yang setring kita jumpai yang merupakan salah satu bentuk bisnis di dunia perdagangan kreatif dan modern. Dengan adanya penjualan cimol ini kita dapat menyediakan suatu jenis makanan ringan dari sekian 
banyaknya makanan ringan, yang terjual di sekitar masyarakat. Makanan ringan yang satu ini memiliki cita rasa yang berbeda dengan makanan yang sejenisnya dikarenakan makanan ini simple dan mudah di buat.

Melihat segala peluang bisnis cimol yang sangat memiliki potensi untuk menjadi sebuah usaha yang dapat dijadikan sebagai alat pendapatan biaya bagi kalangan mahasiswa saat ini, mahasiswa dapat melakukan bisnis ini di luar jam belajarnya atau di luar jadwalnya di kelas. Selain dari itu, tugas mahasiswa dalam melakukan bisnis ini adalah untuk mencari ilmu karena bukan hanya untuk mencari keuntungan atau pendapatan finansialnya. Akan tetapi, kegiatan berwirausaha cimol ini juga dapat dijadikan sebagai salah satu pengalaman yang dapat digunakan mahasiswa dalam proses perkuliahannya yang memang perlu untuk di perdalam dan selalu diperbaiki. Selain dari itu, kegiatan berwirausaha itu juga dapat menjadikan diri setiap mahasiswa untuk menjadi pribadi yang lebih baik kedepannya.

Dalam melakukan atau melaksanakan kegiatan bisnis cimol ini tentunya kita membutuhkan beberapa peralatan dan bahan dalam prose pembuatannya. Diantaranya yaitu :

Tabel 3 Bahan dan Peralatan

\begin{tabular}{|l|l|}
\hline \multicolumn{1}{|c|}{ Bahan } & \multicolumn{1}{c|}{ Alat } \\
\hline 1. Tepung tapioka & $\begin{array}{l}\text { 1. Wajan } \\
\text { 2. Air }\end{array}$ \\
3. Bawang putih & $\begin{array}{l}\text { 3. Tompor } \\
\text { 4. Kaldu ayam bubuk }\end{array}$ \\
5. Merica bubuk & $\begin{array}{l}\text { 4. Spatula } \\
\text { 6. Keju }\end{array}$ \\
7. Bumbu tabur rasa balado dan keju. & 6. Plastic untuk kemasaan produk \\
\hline
\end{tabular}


Cara pembuatan cimol

1. Sediahkan seluruh bahan dan alat yang akan digunakan dalam proses pembuatan cimol.

2. Kemudian sediakan bawang puting untuk di haluskan

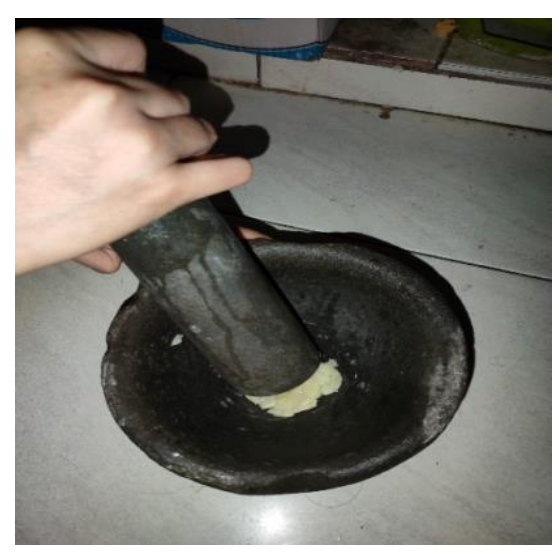

3. Setelah itu Siapkan tepung kanji di dalam baskom

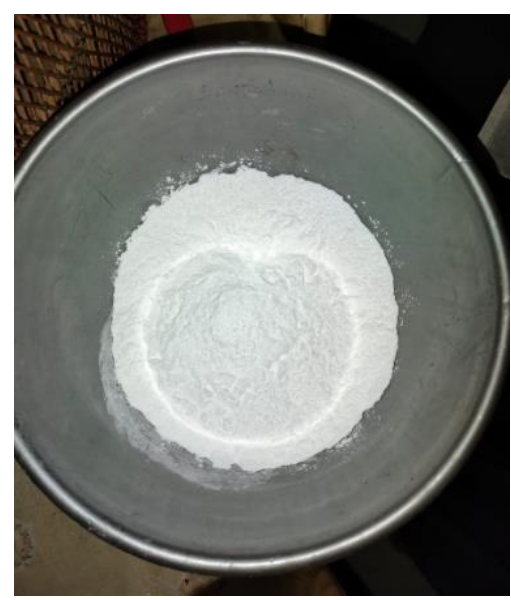

4. Setelah tepung kanji dituang di dalam baskom. Kemudian siapkan panji untuk merebus air.

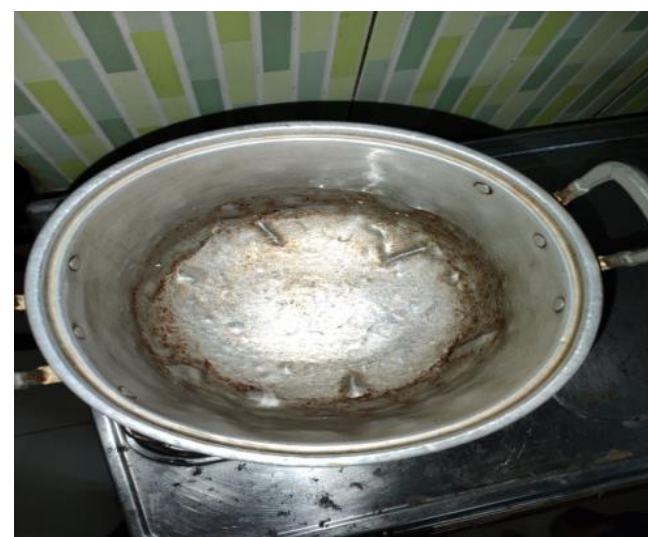

5. Setelah air mendidih tuang secarake dalam tepung kanji lalu uleni tepung kanji 


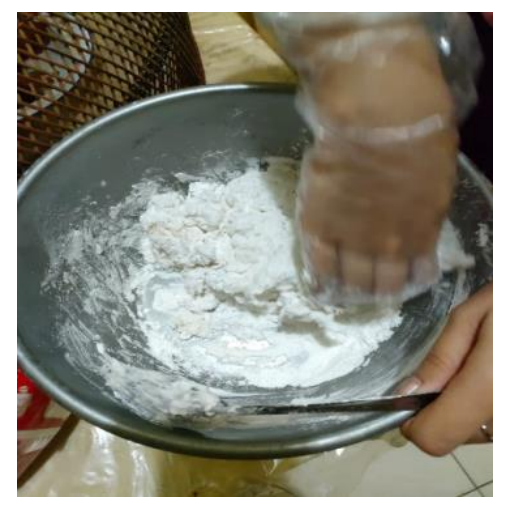

6. Uleni adonan sampai adonan sudah dapat dibentuk bulat-bulat kecil.

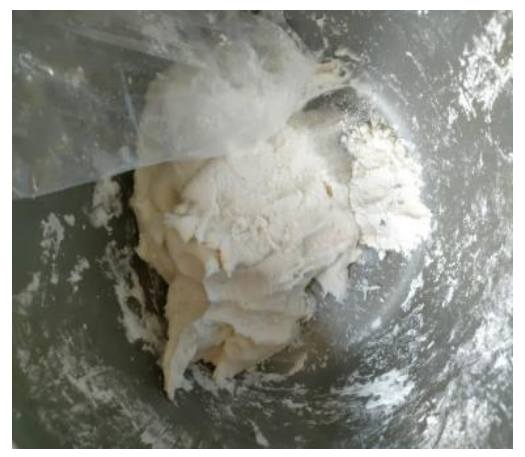

7. Sebelum adonannya di bentuk terlebih dahulu keju di potong-potong kecil sebagai isian dari cimol.

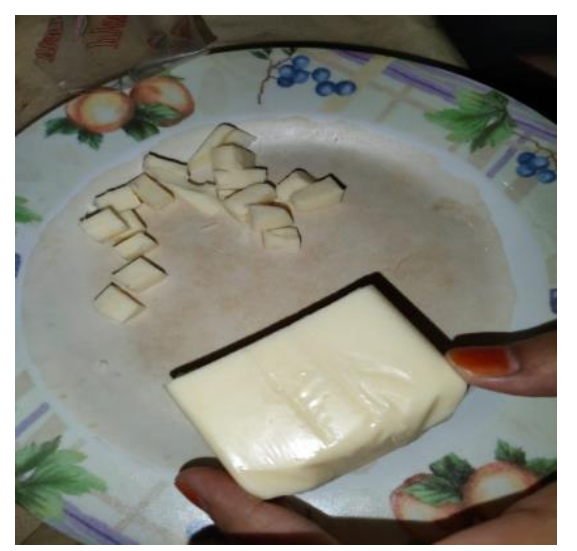

8. Bentuk semua adonan sampai adonannya habis. Dan di barengi dengan mengisi adonan dengan keju.

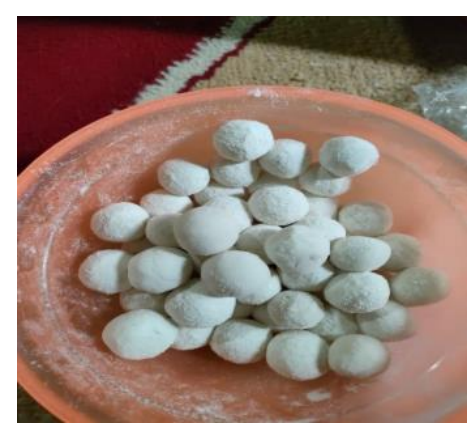


9. Siapkan wajah untuk mengoreng adonan cimol. Akan tetapi, kompor dalam keadaan tidak menyala ini dikarenakan agar adonan tidak meledak saat di goreng.

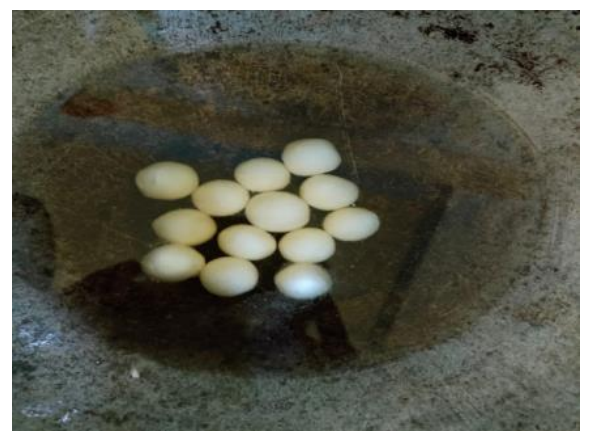

10. Setelah sudah terasa cukup adonan cimol di dalam wajan kemudia nayalakan kompor dengan api yang kecil.

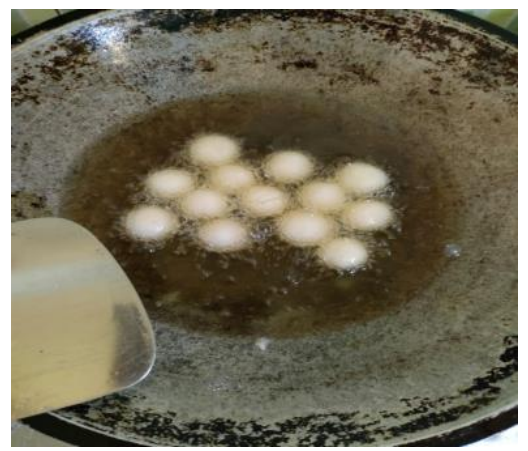

11. Setelah adonan cimol matang tiriskan kemudian beri bumbu balado dan keju.
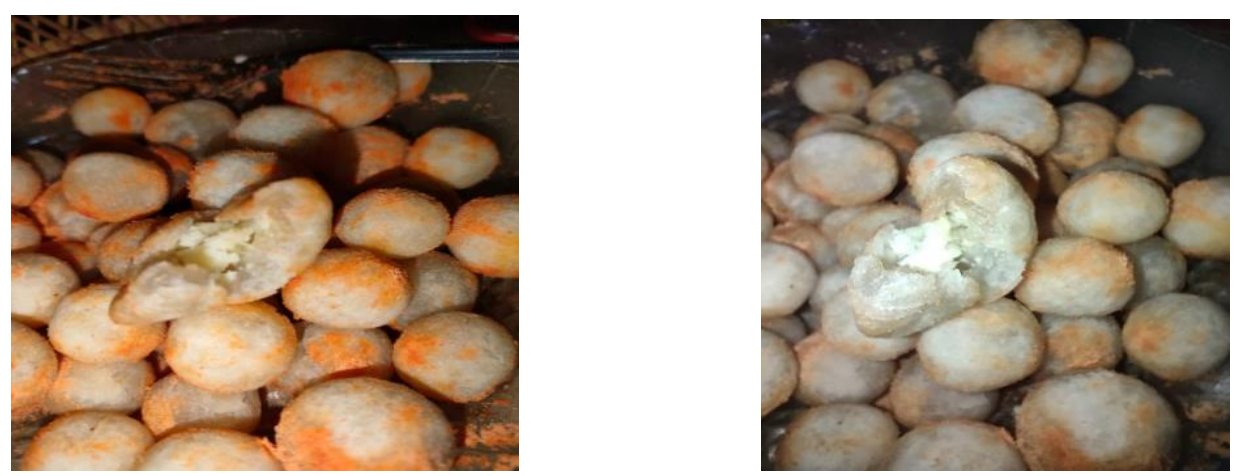

12. Setelah cimol di berikan bumbu kemudian tahap selanjutnya cimol di masukkan ke dalam plastic untuk dipasarkan ke para konsumen.

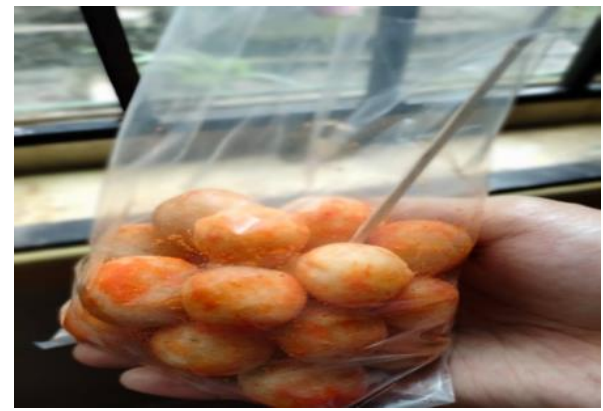




\section{Aspek Rencana Usaha}

1. Aspek pemasaran

Dalam kegiatan usaha ini yang merupakan produk makanan "Cimol", yang tempat pemasarn produknya dekat dari tempat pembuatan produknya dikarenakan tempat pembuatan produknya berada di dalam perumahan sehingga peluang untuk memasarkan produk cimol ini termasuk sebuah peluang pesar apalagi di area perumahan yang pastinya memiliki lingkugan yang sangat dekat dengan masuyarakat terlebih lagi di dalam sebuah perumahan anak-anak dan remaja termasuk mudah untuk di di tawarkan kepada mereka.

2. Aspek ekonomi sosial

Untuk produk makanan cimol ini sangat ekonomis, dikarenakan produk cimol tergolong makanan ringan atau cemilan yang sangat cocok di kantong remaja apalagi bagi kalangan anak-anak. Dan produk cimol juga merupakan makanan ringan yang simple dan praktis karena tidak perluh menggunakan banyak media untuk mengonsumsinya.

3. Analisis SWOT

Sebelum kami jalankan usha kami. Tentunya kami terlebih dahulu melakukan sebuah kegiatan Analisa terhadap lingkungan sekitar terutama lingkungan perumahan yang akan kami tuju. Dengan Analisa ini kami dapat melihat sebuah peluang bagi usaha kami. Termasuk menganalisis ancaman bagi usaha kami.

1) Strength

Produk cimol memiliki rasa yang enak, gurih dan memiliki 2 varian rasa yang kami sediakan. Terbuat dari bahan-bahan yang pastinya bahan yang berkualitas dan juga sehat. Memiliki kemasaan yang praktis, bersih, dan 
sangat mudah untuk dibawah kemana-mana. Dan juga memiliki harga jual yang cukup terjangkau bagi para pelanggan kami.

2) Weakness

Produknya memiliki produsen yang memiliki usaha atau bisnis yang sama. Tingkat gelombang dari beberapa bahan baku yang mungkin akan mengalami perubahan yang tidak bisa bertahan dalam jangka waktu yang lama. Percetakan yang mungkin mmebutuhkan beberapa waktu.

3) Opportunities

Seluruh tingkat konsumen menyukai makanan ringan atau cemilan cimol teruta,a yang berbahan dasar dari tepung aji atau tepung kanji ini. Kami selalu menargetkan konsumen yang membutuhkan makanan atau jajanan yang praktis dan mudah dibawah ketika kita berkegiatan mobile. Para konsumen juga menyukai harga yang cukup terjangkau dan jajanan yang jadul akan tetapi di modernisasikan.

4) Threats

Karena hamper seluruh para konsumen menyukai cemilan cimol maka faktor kompetisi atau daya saing juga sangat ketat dan besar sehingga kita sebagai para produsen produk cemilan cimol tidak boleh sampai legah dalam memasarkan produk apalagi dari segi kualitas dan harga jual maka itu sangat mungkin produk yang kita jual bisa kalah dari produsen lain. Karena itu, mutu dari produk cimol tidak boleh terlewatkan sama sekali karena mutu produklah yang menjadi tolak ukur paling pertama dalam menarik minat para konsumen. 


\section{E. Strategi Pemasaran Produk}

1. Produk

Produk yang kita jual harus memiliki keunikan dan ciri khasnya masing-masing. Dan setiap produk juga harus memiliki nilai ekonomis tersendiri agar produk yang kita pasarkan tetap terjaga kualitasnya tanpa mengesampinkan inovasi pada produk tersebut. Sehingga kita dapat senantiasa menikmati kualitas produk kita baik dari diri sendiri maupun dari semua orang. Dalam penarikan minat para konsumen juga menjadi daya unik tersendiri bagi para pelanggan.

2. Price ( harga )

Dalam penetapan produk usaha biasanya para produsen berlomba-lomba memberikan harga yang murah akan tetapi mereka sebagai para produsen sama sekali tidak memperhatikan kualitas yang terdapat di dalam produknya. Maka dari itu kami menetapkan harga sesuai dengan seberapa banyak yang di inginkan para konsumen. Harga yang kami tawarkan untuk produk cimol kami yaitu mulai dari Rp. 5.000 sampai dengan Rp. 10.000 perporsinya.

3. Promosi

Promosi merupakan kegiatan yang biasnya dilakukan oleh para produsen untuk memperkenalkan produk yang akan mereka tawarkan kepada para konsumen baik itu produk jasa ataupun produk barang. Hal ini bertujuan untuk membangun perspektif masyarakat luas atas produk atau jasa yang akan ditawarkan kepada mereka. Konsep promosi biasanya dilakukan dalam beberapa konsep periklanan diantarnya : public relation, promosi penjualan, menjual sendiri, dan pemasaran lansung. Akan tetapi, pada promosi kali ini untuk produk cimol kami media promosi yang kami gunakan yaitu :

- Offline, para tahap proses promosi ini kami lakukan dengan cara face to face. Yaitu kami memperkenalkan produk kami secara lansung dari satu orang ke orang lain sehingga kabar produk kami tersebar ke beberapa kalangan konsumen.

- Online, ,pada tahap ini kami gunakan media sosial untuk memperkenalkan produk cimol kami. Adapun media sosial yang kami manfaatkan dalam hal 
ini yaitu whatshaap, Instagram, telegram dll. Hal ini bertujuan untuk memperkenalkan produk kami secara luas.

\section{F. Rencana Anggaran Biaya ( RAB )}

\section{Rencana Anggaran biaya ( RAB )}

Tabel 4 RAB Peralatan ( Fix Cost)

\begin{tabular}{|c|c|c|c|c|c|}
\hline No & Nama & Satuan & Jumlah & $\begin{array}{c}\text { Harga } \\
\text { Satuan } \\
(\mathrm{Rp})\end{array}$ & $\begin{array}{r}\text { Jumlah } \\
\text { harga }(R p)\end{array}$ \\
\hline 1. & Tabung Gas & $\mathrm{Kg}$ & 1 & Rp 20.000 & $\operatorname{Rp} 20.000$ \\
\hline 2. & Plastik Kemasan & Bks & 1 & Rp 6.000 & Rp 6.000 \\
\hline \multicolumn{5}{|c|}{ Total } & $\operatorname{Rp} 26.000$ \\
\hline
\end{tabular}

Tabel 5 RAB Bahan ( Variable Cost)

\begin{tabular}{|c|l|c|c|c|c|}
\hline No & \multicolumn{1}{|c|}{ Nama } & Satuan & Jumlah & $\begin{array}{r}\text { Harga } \\
\text { Satuan } \\
(\mathrm{Rp})\end{array}$ & $\begin{array}{c}\text { Jumlah } \\
\text { harga (Rp) }\end{array}$ \\
\hline 1. & Tepung Tapioka & Bks & 1 & Rp 5.500 & Rp 5.500 \\
\hline 2. & Minyak Goreng & Lit & 1 & Rp 17.500 & Rp 17.500 \\
\hline 3 & Bawang Putih & Siung & 2 & Rp. 2.500 & Rp. 2.500 \\
\hline 4 & Kaldu Ayam Bubuk & Bks & 5 & Rp. 1.000 & Rp. 1.000 \\
\hline 5 & Merica Bubuk & Bks & 2 & Rp. 1.000 & Rp. 1.000 \\
\hline 6 & Keju & Bks & 1 & Rp. 11.500 & Rp. 11.500 \\
\hline 7 & Bumbu Tabur (Balado) & Bks & 1 & Rp. 5.000 & Rp. 5.000 \\
\hline
\end{tabular}

\section{Perhitungan Biaya}

Total Anggaran Biaya yang dikeluarkan selama periode penjualan usaha kuliner cimol.

1. Biaya Peralatan = Rp. 26.000

$\begin{array}{ll}\text { 2. Biaya Bahan } & =\text { Rp. } 47 \cdot 000+ \\ \text { Total } & =\text { Rp. } 73 \cdot 000 \\ \text { Modal Awal } & =\text { Rp. } 100.000\end{array}$

$$
\begin{aligned}
\text { Modal Awal }- \text { Total Biaya Biaya } \quad=\text { Rp. } 100.000-\text { Rp. } 73.000 \\
=\text { Rp. } 27.000(\text { Sisa Modal })
\end{aligned}
$$




\section{Perhitungan Penghasilan}

Pada pembuatan usaha kuliner cimol, menjalankan usahanya selama 1 bulan, yang dimana usaha tersebut dijalankan di saat produsen berada di waktu luang atau di luar jadwal perkuliahan, menghasilkan penjualan :

- Minggu Pertama = Rp. 30.000

- Minggu Kedua = Rp. 50.000

- Minggu Ketiga = Rp. 70.000

- Minggu Keempat = Rp. $90.000+$

Total $=$ Rp. 240.000

\section{Perhitungan Laba / Rugi}

1. Penghasilan Usaha = Rp. 240.000

2. Biaya yang Dikeluarkan $=$ Rp. 73.000

Jadi Laba / Rugi = Biaya Penghasilan - Biaya Pengeluaran

$=$ Rp. $240.000-$ Rp. 73.000

$=$ Rp. 167.000

Sisa Modal

$=$ Rp. 27.000

$=$ Rp. $167.000-$ Rp. 27.000

Laba Bersih = Rp. $140.000(1$ Bulan $)$

Jumlah kas keseluruhan $=$ Sisa Modal + Laba Bersih

$=$ Rp. $27.000+$ Rp. 140.000

$=$ Rp. 167.000 


\section{BAB III}

\section{PENUTUP}

\section{A. Kesimpulan}

Produk bisnis Cimol sebagai makanan atau cemilan yang memiliki rasa gurih yang dikerasikan dengan tambahan isi keju didalamnya, dan diberi taburan bumbu dan dikemas dengan akan menarik yang tentu saja akan diminati oleh semua kalangan. Bisnis yang akan kami jalani bisa menjadi bisnis yang terkenal hingga luar daerah, jika kami serius dan tekun menjalaninya. Kita tidak bisa memulai bisnis secara sembarang meskipun usaha tersebut berupa sebuah usaha sampingan. Akan tetapi, Kegagalan sebenarnya bukan disebabkan oleh orang lain namun kegagalan tersebut berasal dari diri kita sendiri, dengan begitu ketekunan dalam menjalankannya adalah suatu keharusan dan bersifat wajib untuk di lakukan. Perhitungan yang matang sebaiknya dilakukan pada awal-awal kita memulai usaha karena sekali kita salah dalam perhitungan yang harusnya dihitung lebih awal maka yang akan terjadi adalah efek berantai dimana kita akan terus menerus mengalami kesalahandan juga kegagalan yang Sudah sewajarnya jika kita ingin memulai usaha seharusnya kita belajar terlebih dulu kepada mereka yang lebih sukses agar kita dapat memilih mana yang pas dan mana yang kurang. Dengan demikian kita akan terhindar dari beberapa resiko yang besar bagi bisnis yang telah direncanakan. Bisnis ini akan kami buat dengan sebaik mungkin sehingga usaha kami berjalan terus dan bisa membuka lowongan pekerjaan bagi masyuarakat luas apabila konsumen sudah melampaui batas yang tidak bisa kami kendalikan. Bisnis ini juga akan di dipromosikan dimedia sosial sehingga banyak konsumen yang tertarik dan membelinya karena manusia memiliki sifat yang penasaran akan sesuatu hal yang ada disekitarnya meskipun itu hanya hal kecil. Kami yakin usaha 
Cimol ini akan berjalan dengan baik dan lancar karena kami akan bekerjasama dalam melanjarkan dan melaksanakan kegiatan bisnisnya.

\section{B. Saran}

Dapat memberikan infomasi tentang bidang usaha yang sedang ditekuni dan akan memberikan jaminan sukses dalam penjualannya atau peluang usaha yang di tekuni sebagai usaha sampingan dan juga memberikan kita pembelajaran untuk berwirausaha. 
HASIL DOKUMENTASI

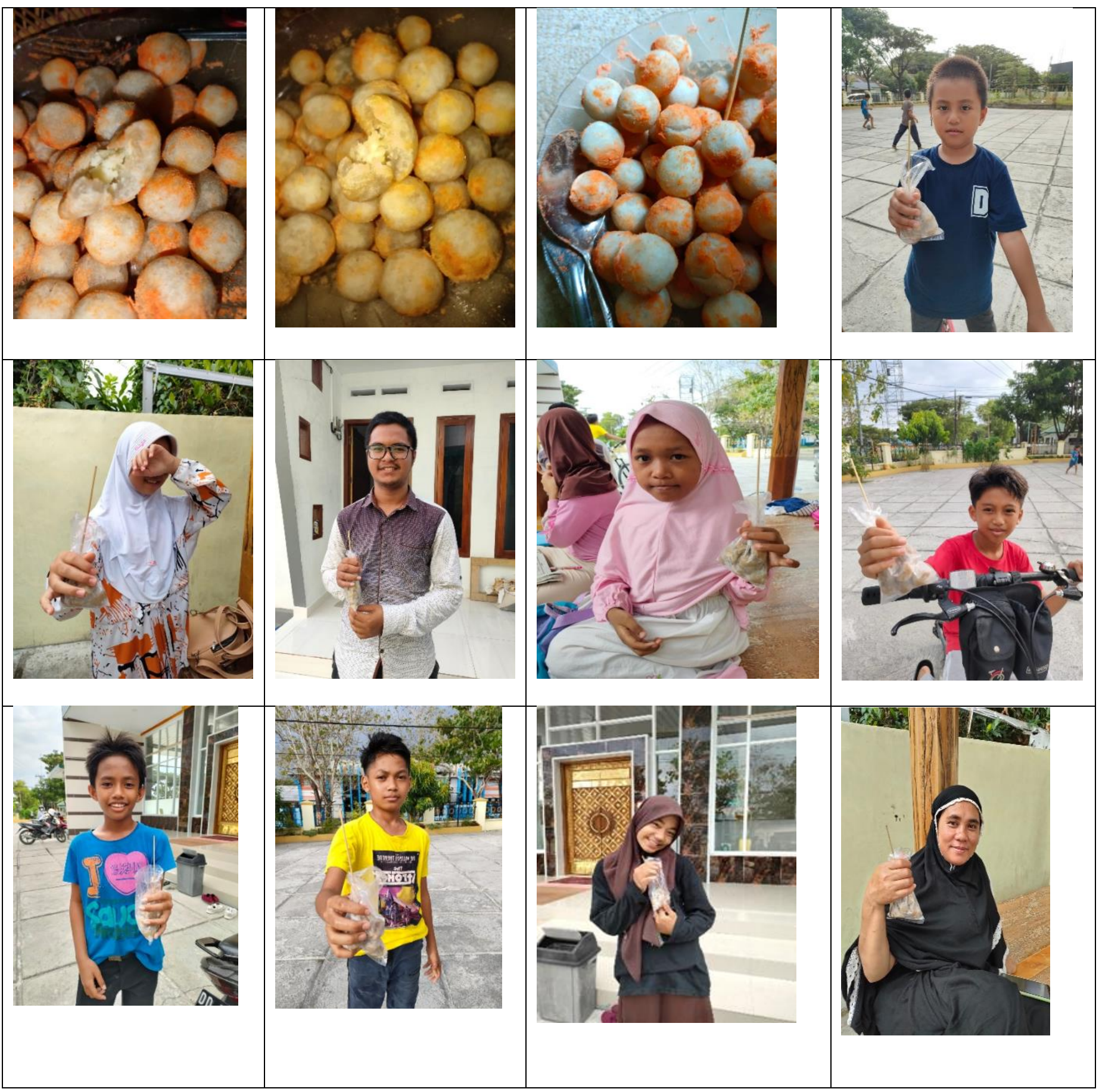




\section{DAFTAR PUSTAKA}

https://id.wikipedia.org/wiki/Cimol

http://noviasantibudoyo.blogspot.com/2017/12/tugas-kewirausahaan.html?m=1

https://pdfcoffee.com/proposal-kwu-kelompok-10-pdf-free.html

https://www.academia.edu/19630251/Kewirausahaan_CIGOSI_cimol_goreng_isi_

https://tukangreview.com/cara-membuat-cimol/ 